\title{
Effect of Angle of Attack on Pressure and Lift Coefficient of ONERA OA206 Wing Model Using Computational Fluid Dynamics Method
}

\author{
Resti Anggraeni ${ }^{1 . a}$ \\ ${ }^{1}$ Forum Kajian Komputasi (FKK), Jl. Ekajaya No.6 RT.1 RW.8 Dusun Pondok Waluh, \\ Desa Wringinagung Kecamatan Jombang, Jember, 68168 \\ aanggra.resti98@gmail.com
}

\begin{abstract}
In this study, we computed the lift force of the aircraft with ONERA OA206 airfoil type. It was positioned at $0 \%, 25 \%, 50 \%, 75 \%$, and $100 \%$ of the wingspan for Angle of Attack (AoA) variations of $0^{\circ}$, $4^{\circ}, 8^{\circ}, 12^{\circ}$, and $16^{\circ}$. The research was to determine the effect of AoA on pressure, pressure coefficient $\left(C_{\mathrm{p}}\right)$, and lift coefficient $\left(C_{\mathrm{L}}\right)$ on the ONERA OA206 aircraft wing. It shows that the greater AoA on the result of the pressure contour causes the increase in the difference of span at AoA $0^{\circ}$ to $16^{\circ \mathrm{t}}$ these are $0.25 \% ; 0.26 \% ; 0.43 \% ; 0.52 \%$; and $0.53 \%$. Through the graph of the pressure coefficient $\left(C_{\mathrm{p}}\right)$ against $x / c$, it can be seen that the greater AoA, the expansion point, and the stagnation point will shift to the right with the direction of $x / c$. In addition, the $C_{p}$ at the lower is greater than the upper of the airfoil. Based on the research results, it was found that $C_{\mathrm{L}}$ at the position of $0 \%$ to $50 \%$ increased when given AoA from $0^{\circ}$ to $12^{\circ}\left(C_{\mathrm{L}} \max \right)$ and decreased at $\mathrm{AoA}=16^{\circ}$ (stall). Meanwhile, $C_{\mathrm{L}}$ at $75 \%$ to $100 \%$ increased when given AoA from $0^{\circ}$ to $8^{\circ}\left(C_{L} \max \right)$ and decreased at $A o A=12^{\circ}$ (stall). With these results, it can be concluded that the maximum AoA that can be applied to the wing of the ONERA OA206 aircraft is $8^{\circ}$. The closer to the end position of the airfoil, the higher the $C_{\mathrm{L}}$ measured.
\end{abstract}

Keywords: ONERA OA206, Angle of Attack, Pressure, Pressure Coefficient, Lift Coefficient.

\section{Introduction}

The transportation sector has developed rapidly, namely the development of aircraft transportation modes. The first aircraft to date have undergone various developments and modifications to optimize work and aircraft reliability. One of the important modifications that need to be made is the components or aerodynamic factors of the aircraft. In this term, one important aerodynamic component of airplanes is the wing. For example, wing analysis is based on arranged airfoil shapes. An Airfoil is a geometric constituent of the wing that causes lift and drag [1]. Airfoil design will determine the lift and drag which is influenced by pressure. In this paper, research was conducted using an ONERA OA206 airfoil model. The reason for selecting ONERA objects is due to their widespread and commercial use in aeronautics such as Airbus, Ariane, Rafale, Falcon, Mirage, and Concor. One example of an Airbus type aircraft is the widebody aircraft used from 1974 to the present day and is the largest passenger aircraft in the world. The difference in airfoil geometry generally lies in the thickness, camber, and chord values that affect the design and coordinates. The research objective was to determine the effect of AoA on pressure, pressure coefficient $\left(C_{\mathrm{p}}\right)$, and lift coefficient $\left(C_{\mathrm{L}}\right)$ on the ONERA OA206 aircraft wing.

In this study, a CFD (Computational Fluid Dynamics) simulation of the effect of AoA on the ONERA OA206 wing was carried out by measuring the airfoil located at $0 \%, 25 \%, 50 \%, 75 \%$, and $100 \%$ of the wingspan. The changes of AoA that are given to each position are $0^{\circ}, 4^{\circ}, 8^{\circ}$, $12^{\circ}$, and $16^{\circ}$. Each airfoil will produce a different pressure plot. The pressure plot is then 
connected to the pressure coefficient $\left(C_{\mathrm{p}}\right)$, and the pressure coefficient value is used to determine the value of the lift coefficient $\left(C_{\mathrm{L}}\right)$. The lift coefficient $\left(C_{\mathrm{L}}\right)$ can determine the maximum AoA that can be achieved by the ONERA OA206 wing. Aircraft wing construction in this study uses the CFD method which is assisted by the Solidworks 2019 software.

\section{Theoretical Background}

CFD refers to the form of moving fluid and how the nature of the fluid flowing can affect possible processes and others. The physical characteristics of the motion of fluids can usually be described by mathematical basic equations, usually in the form of partial differentials. The solution to these mathematical equations is converted by computer scientists using computer programming languages into software [2]. Aerodynamics can be defined as a force or change in motion of an object due to air resistance when the object is traveling fast. Objects can be vehicles or transportation on land, sea, or air which are closely related to aerodynamic developments to date. One of the objects that are included in aerodynamics is an aircraft. To design an aircraft, it is necessary to calculate very carefully the initial design of the aircraft [3].

Initial estimates in the design of an aircraft are based on the characteristics of the aerodynamics themselves, namely the size of the drag and lift of an aircraft. Air flowing through the fuselage will be diverted from its original path, causing a change in airspeed. This change in velocity can be expressed by the Bernoulli equation which shows that the pressure exerted by the air on the plane changes the flow from laminar flow (regular or parallel flow) to turbulent flow (disturbing or irregular flow). Apart from this, the viscosity of the air also creates a friction force that tends to restrain the airflow [3].

An Airfoil is a geometric shape on the wing that will cause the lift to be greater than drag when placed in a fluid flow. One of the factors causing the large or small lift on the airfoil is the geometric shape (maximum thickness). Other factors that determine the average velocity of airflow on the airfoil surface are the amount of Angle of Attack (AoA) and the velocity of the fluid flow [1]. The greater the AoA $(\alpha)$, the more airflow tends to separate from the upper surface of the airfoil and form a large ulcer (dead air) on the back of the airfoil. In this separation flow, the airflow rotates and part of the flow moves in the opposite direction to the free stream flow, also called reversed flow. The separated flow is an effect of viscosity. The consequence of separate that flow at high $\alpha$ is a reduction in lift and an increase in drag due to pressure drag, this condition is called a stall condition [4].

ONERA (Office National d'Etudes et de Recherches Aérospatiales) is France's national aerospace research center. ONERA is a public company with industrial and commercial operations and conducts application-oriented research to support increased innovation and competitiveness in the aerospace and defense sectors. The department of Aerodynamics (ONERA) designed the ONERA M6 wing in 1972 [5].

Experiments on the ONERA M6 involved the over-wing flow tested in a wind tunnel on each transonic (20\%, 44\%, 65\%, 80\%, 90\%, 95\%, and 99\%) and an Angle of Attack up to $6^{\circ}$. The Reynold number used is about $12,000,000$ based on the aerodynamic chord average. The wind tunnel test was documented by Schmitt and Charpin in the AGARD Report AR-138 published in 1979 [6]. 
The flow field conditions used are taken from the 2308 reference test 1 . CFD simulations were carried out using the flow conditions listed in Table 1. The number of Reynold numbers used is 11.72 million based on the aerodynamic chord average length of 0.64607 meters [7].

Table 1. Flow conditions in the 2308 test reference 1 [7]

\begin{tabular}{cccc}
\hline Mach & Reynold Number & le angle of Attack $\left({ }^{\circ}\right)$ & The angle of Slideslip $\left(^{\circ}\right)$ \\
\hline 0.8395 & 11720000 & 3.06 & 0.0 \\
\hline
\end{tabular}

The ONERA M6 wing is a semi-span wing, using asymmetrical airfoil of the ONERA $D$ type. The airfoil section coordinates in the plane $(y / b)=0.0$ from Schmitt and Charpin's report and the airfoil coordinates in an ASCII text file describing the thickness limit of the trailing edge (zero). The geometric layout of the wings is shown in Figure 1(a) and some geometric properties are shown in Table 2. The test results obtained are the distribution of the pressure coefficient $\left(C_{\mathrm{p}}\right)$ on the wing surface as shown in Figure 1(b) [6].

Table 2. Description of the geometry of the ONERA M6 wing [6]

\begin{tabular}{cc}
\hline Parameter & Value \\
\hline Span. b & 1.1963 meters \\
Mean Aerodynamic Chord. c & 0.64607 meters \\
Taper Ratio & 3.8 \\
Leading-edge Sweep & $30^{\circ}$ \\
Trailing-edge Sweep & $15.8^{\circ}$ \\
\hline
\end{tabular}

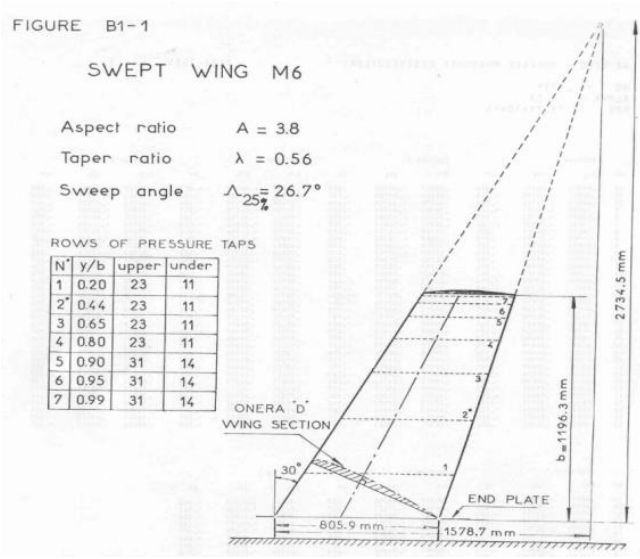

(a)

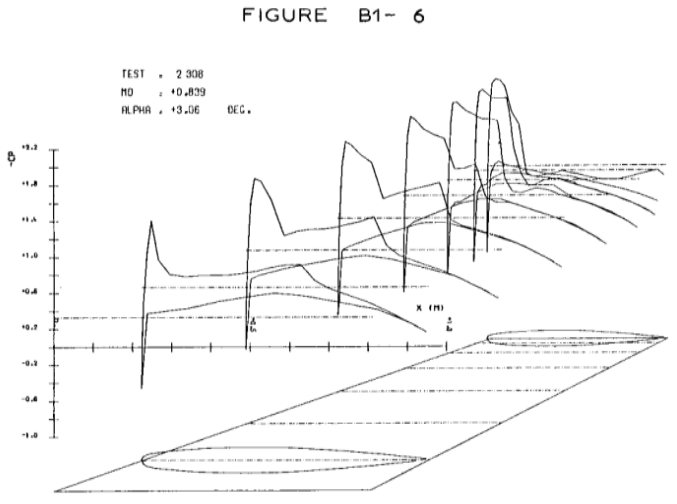

(b)

Figure 1. (a) The geometry of the wing and (b) Graph of the pressure coefficient of the ONERA M6 [7]

The pressure coefficient $\left(C_{p}\right)$ is used to represent the relative static pressure distribution in the flow on upper wings. The pressure distribution can be analyzed with the help of the pressure coefficient. The lift coefficient (lift) and the drag coefficient can also be calculated with the pressure coefficient. The pressure distribution was analyzed by plotting the pressure coefficient distribution $\left(C_{\mathrm{p}}\right)$ with different results at locations along the span of $20 \%, 44 \%, 65 \%, 80 \%, 90 \%$, $95 \%$, and $99 \%$ of the wingspan length [8]. 
According to Lakshman et al. (2018) [8], plotted the data obtained that as the distance from the wing roots increases, the lower subsurface pressure distribution is more affected. This is because the induced flow (secondary flow) near the end of the lower surface flows towards the upper surface. This induced flow can be reduced using winglets and other methods, resulting in an increase in lift distribution [8].

According to Sogukpinar and Bozkurt (2015) [9], their study using a simulated NACA 2415 airfoil with low airflow velocity to determine the optimal angle of attack against an aircraft wing. The numerical results of the simulations are compared with experimental data to validate the calculation of CFD accuracy. Numerical experiments were carried out by varying the angles of $4^{\circ},-2^{\circ}, 0^{\circ}, 2^{\circ}, 4^{\circ}, 6^{\circ}, 8^{\circ}$, and $10^{\circ}$ with a wind speed of $19.6 \mathrm{~m} / \mathrm{s}$ and a Reynold number of $3,000,000$. As a result, increasing the angle of attack from $-4^{\circ}$ to $10^{\circ}$ causes a difference in the change in pressure between the upper and lower surfaces. The increase in angle causes a rapid decrease in pressure on the upper surface, while on the lower surface causes a slower increase in pressure. The study results show that the maximum lift to drag ratio is achieved at an angle of $4^{\circ}$.

According to Murakami (1993) [10], the pressure coefficient $\left(C_{p}\right)$ on incompressible flow is defined as follows:

$C_{p} \equiv \frac{p-p_{\infty}}{\frac{1}{2} \rho_{\infty} V_{\infty}{ }^{2}}$

Information:

$p \quad$ : initial pressure $\left(\mathrm{N} / \mathrm{m}^{2}\right)$

$p_{\infty}:$ far-field pressure $\left(\mathrm{N} / \mathrm{m}^{2}\right)$

$V_{\infty}:$ far-field air velocity $(\mathrm{m} / \mathrm{s})$

$\rho_{\infty}:$ far-field density $\left(\mathrm{kg} / \mathrm{m}^{3}\right)$

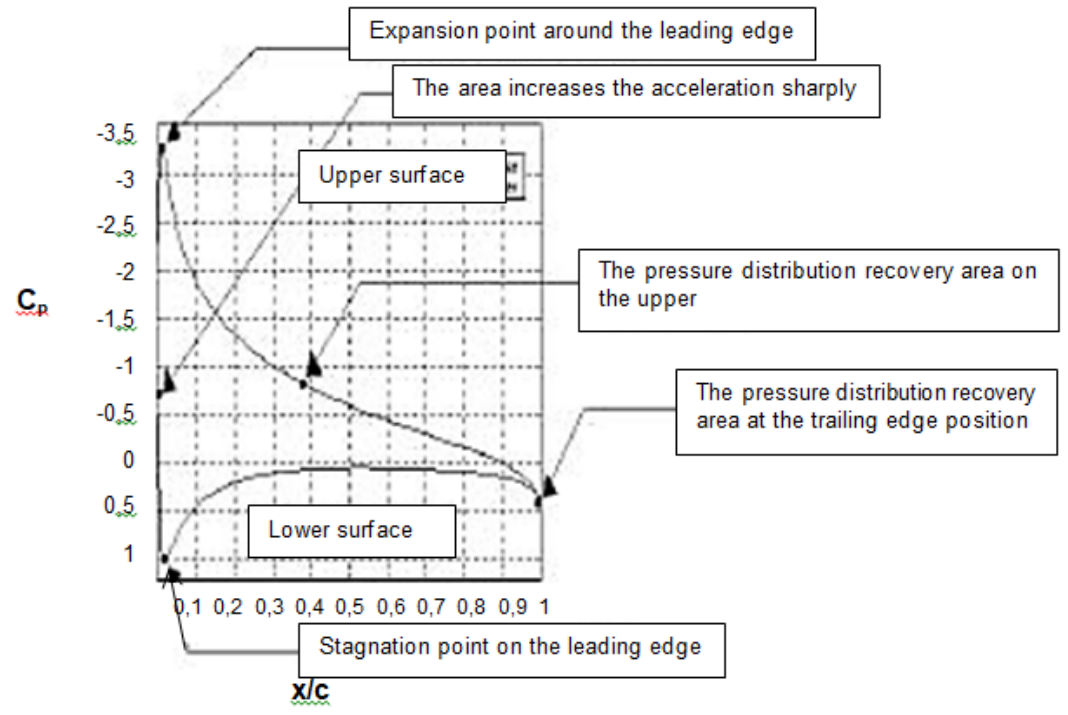

Figure 2. Graph of the aerodynamic characteristics of Cp against x/c [11] 
The lift on the airfoil depends on the lift coefficient generated by the airfoil. The lift coefficient $\left(C_{\mathrm{L}}\right)$ is influenced by the design of the camber shape of the airfoil. The $C_{\mathrm{L}}$ generated by an airfoil varies linearly with a certain angle of attack $(A \circ A)$. As the AoA increases, the airfoil tends to separate from the top surface of the airfoil, forming a large "dead air" loop behind the airfoil. In this separation flow, the airflow rotates and part of the flow moves in the opposite direction to the free stream flow, also called reversed flow.

The separated flow is an effect of viscosity. The consequence of the separate flow at high $\alpha$ is a reduction in lift and an increase in drag due to pressure drag, this condition is called a stall condition. The maximum $C_{\mathrm{L}}$ value right before stall conditions is denoted by $C_{\mathrm{L}} \max . C_{\mathrm{L}} \max$ is the most important aspect of airfoil performance, because it determines the aircraft stall speed, especially during critical flight phases, namely flying, taking off, and landing [12].

According to Harahap (2003) [11], the value of the coefficient of lift $\left(C_{\mathrm{L}}\right)$ is defined by the following equation:

$$
C_{L}=\frac{1}{c}\left[\int_{0}^{c}\left(C_{p_{l}}-C_{p_{u}}\right) \partial x\right]
$$

information:

$C_{L} \quad$ : lift coefficient

$c$ : chord length $(\mathrm{m})$

$C_{p_{l}}$ : the average value of the pressure coefficient on the lower airfoil

$C_{p_{u}}$ : the average value of the pressure coefficient on the upper of the airfoil

\section{Methods}

The research was done using CFD Solidworks 2019 program for simulatingONERA OA206 airfoil, (airfoil coordinates can be seen in https://airfoiltools.com). The simulation was done for the airfoil position at $0 \%, 25 \%, 50 \%, 75 \%$, and $100 \%$ of the wingspan. The variations of angle of attack were used for degrees $0^{\circ}, 4^{\circ}, 8^{\circ}, 12^{\circ}$, and $16^{\circ}$. The output of simulations was pressure plot, pressure coefficient graph $\left(C_{\mathrm{p}}\right)$, and lift coefficient graph $\left(C_{\mathrm{L}}\right)$.

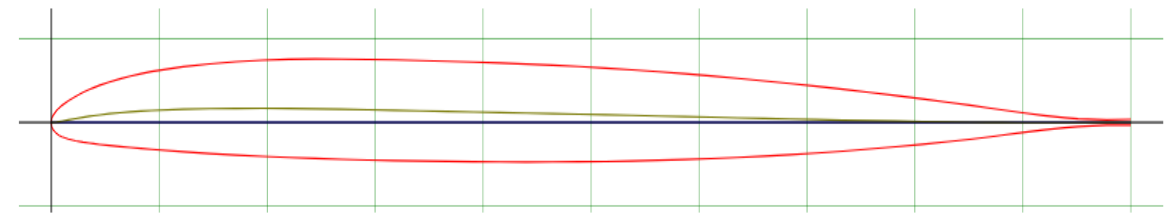

Figure 3. The geometry of airfoil ONERA OA206 


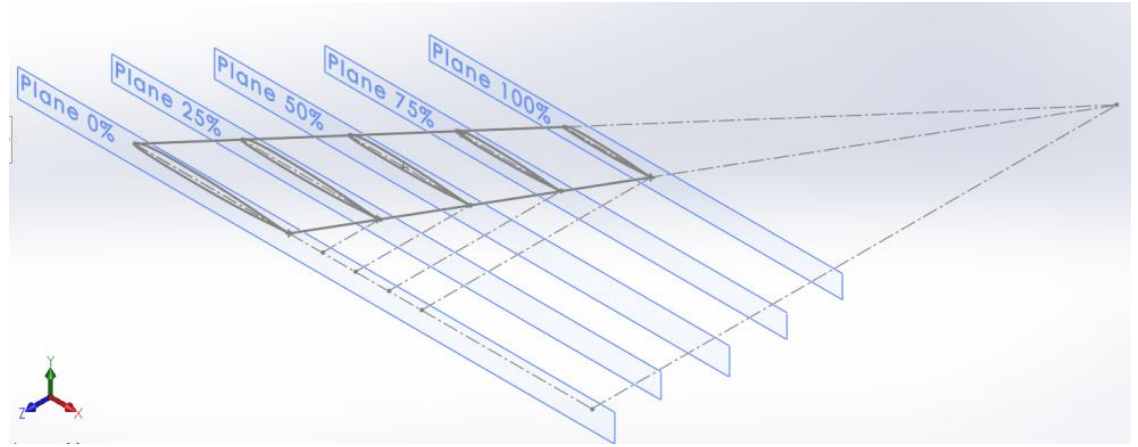

Figure 4. Position of the airfoil of ONERA OA206 wing

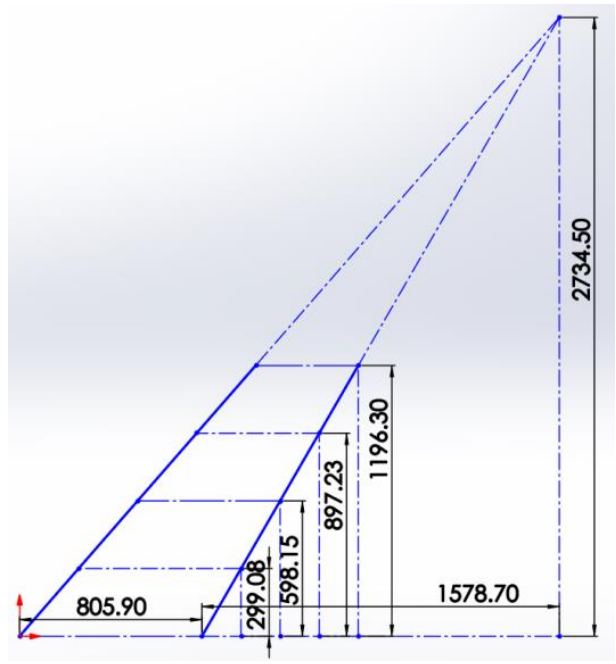

Figure 5. Position of airfoil on span wing ONERA OA206 (y/b)

Table 2. Parameters for limit condition

\begin{tabular}{ccc}
\hline Parameter & Value & Unit \\
\hline fluid speed & $65.27^{\text {(a) }}$ & $\mathrm{m} / \mathrm{s}$ \\
fluid pressure & $101325^{\text {(a) }}$ & $\mathrm{Pa}$ \\
temperature & $303.8^{\text {(a) }}$ & $\mathrm{K}$ \\
gravity & $9.81^{(\mathrm{a}}$ & $\mathrm{m} / \mathrm{s}^{2}$ \\
fluid mass density & $0.59^{\text {(a) }}$ & $\mathrm{kg} / \mathrm{m}^{3}$ \\
fluid dinamic viscousity & 0.000018 & $\mathrm{~m}^{2} / \mathrm{s}$ \\
Global mesh resolution level & 7 & - \\
\hline
\end{tabular}

Source: (a) Kurniawan (2018) 
Computational and Experimental Research in Materials and Renewable Energy (CERiMRE)

Volume 2, Issue 2, page 81-97

eISSN : 2747-173X
Submitted : August 2, 2019

Accepted : October 15, 2019

Online : November 24, 2019

doi : $10.19184 /$ cerimre.v2i2.27374

Table 3. Parameter of airfoil chord length at wing and angle of attack

\begin{tabular}{ccc}
\hline Parameter & Value & Unit \\
\hline at position $0 \%(\mathrm{y} / \mathrm{b})$ & 0.806 & $\mathrm{~m}$ \\
at position $25 \%(\mathrm{y} / \mathrm{b})$ & 0.718 & $\mathrm{~m}$ \\
at position $50 \%(\mathrm{y} / \mathrm{b})$ & 0.630 & $\mathrm{~m}$ \\
at position $75 \%(\mathrm{y} / \mathrm{b})$ & 0.541 & $\mathrm{~m}$ \\
at position $100 \%(\mathrm{y} / \mathrm{b})$ & 0.453 & $\mathrm{~m}$ \\
Angle of attack & 0.4 .8 .12 .16 & $\left(^{\circ}\right.$ \\
\hline
\end{tabular}

Table 4. Parameter of the computational domain

\begin{tabular}{ccc}
\hline Parameter & Value & Unit \\
\hline$x \max$ & 1.5 & $\mathrm{~m}$ \\
$x \min$ & -0.7 & $\mathrm{~m}$ \\
$y \max$ & 1 & $\mathrm{~m}$ \\
$y \min$ & -0.5 & $\mathrm{~m}$ \\
$z \max$ & 0.002 & $\mathrm{~m}$ \\
$z \min$ & -0.002 & $\mathrm{~m}$ \\
Computational domain & $2 \mathrm{D}$ & - \\
\hline
\end{tabular}

\section{Results and Discussions}

\section{Effect of AoA on Pressure Plot}

For a variation of airfoil positions (chord) at the wing of ONERA )A206 then we can see some important pictures as below:

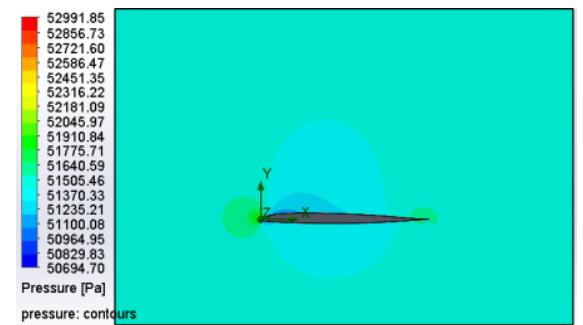

(a) $\mathrm{AoA} 0^{\circ}$

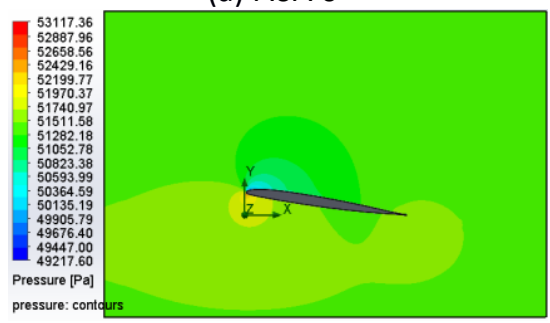

(c) $A \circ A 8^{\circ}$

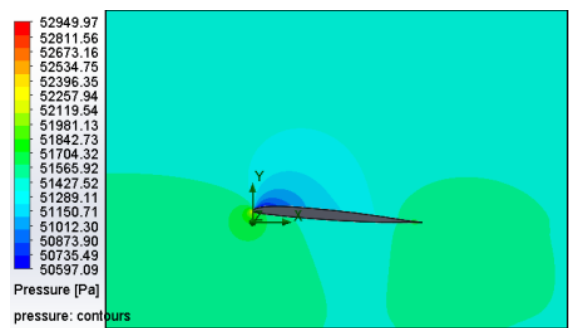

(b) $\mathrm{AoA} 4^{\circ}$

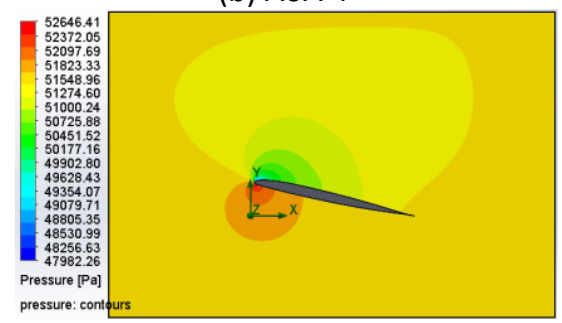

(d) AoA $12^{\circ}$ 


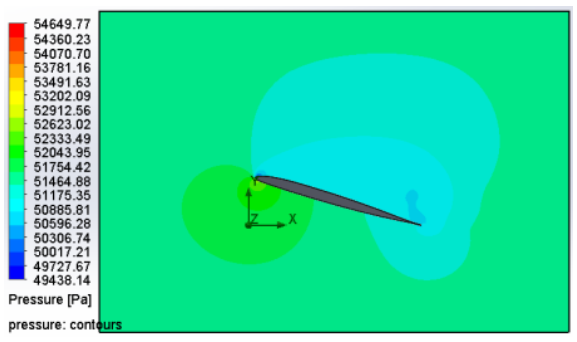

(a) (e) AoA $16^{\circ}$

Figure 6. Pressure contour of airfoil ONERA OA206 at position $0 \%$ of span length

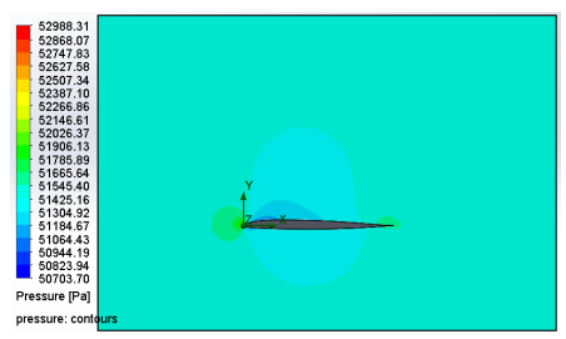

(a) $\mathrm{AoA} 0^{\circ}$

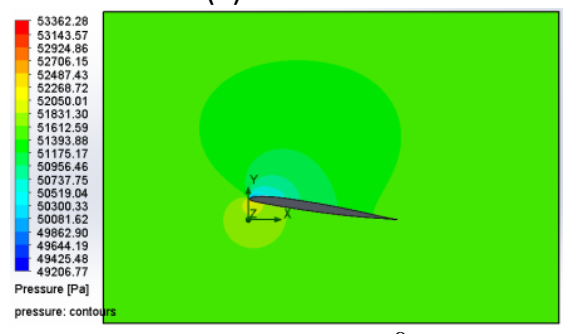

(c) $\mathrm{AoA} 8^{\circ}$

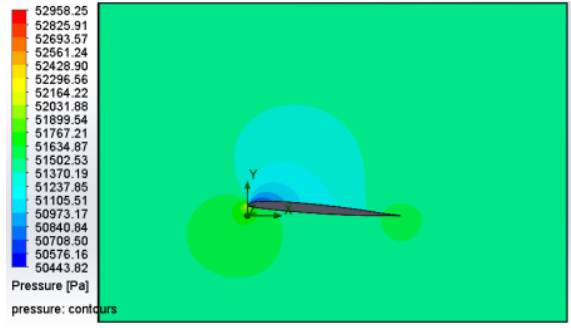

(b) $\mathrm{AoA} 4^{\circ}$

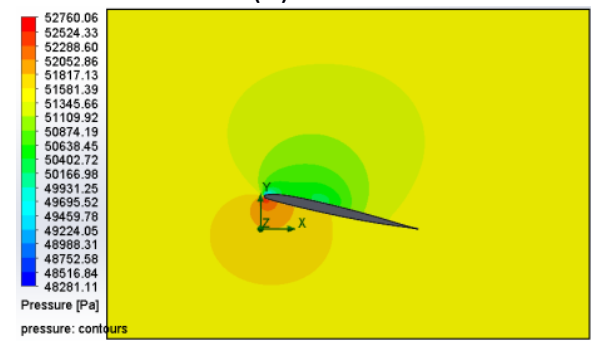

(d) AoA $12^{\circ}$

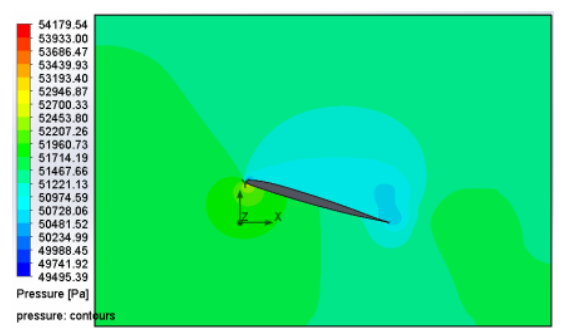

(e) AoA $16^{\circ}$

Figure 7. Pressure contour of airfoil ONERA OA206 at position $25 \%$ of span length 
Computational and Experimental Research in Materials and Renewable Energy (CERiMRE)

Volume 2, Issue 2, page 81-97

eISSN : 2747-173X
Submitted : August 2, 2019

Accepted : October 15, 2019

Online : November 24, 2019

doi : $10.19184 /$ cerimre.v2i2.27374

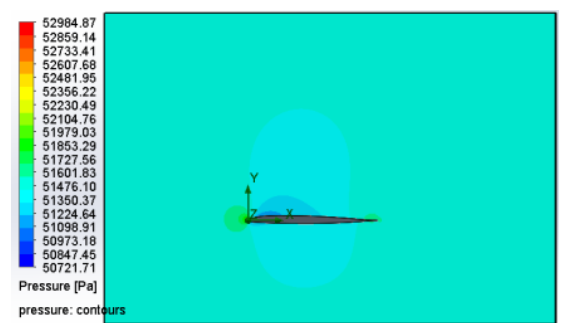

(a) AoA $0^{\circ}$;

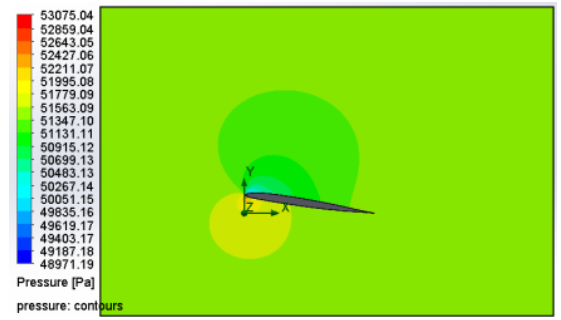

(c) $\operatorname{AoA} 8^{\circ}$

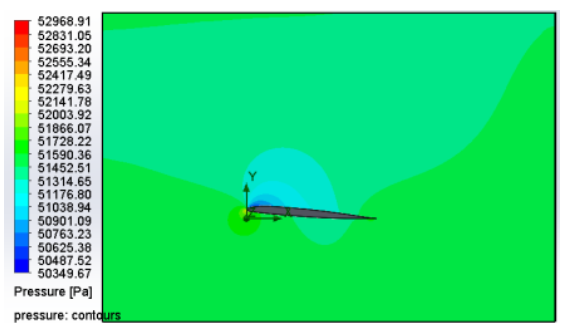

(b) $\mathrm{AoA} 4^{\circ}$

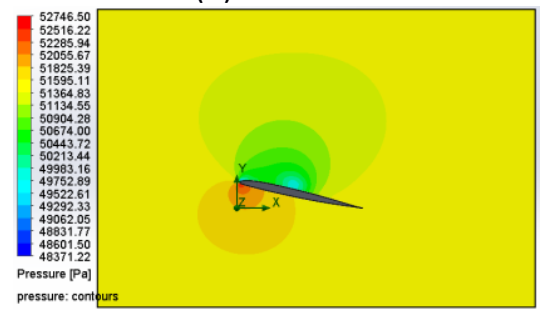

(d) AoA $12^{\circ}$

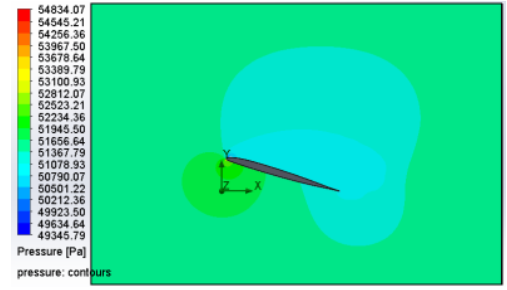

(e) $\mathrm{AoA} 16^{\circ}$

Figure 8. Pressure contour of airfoil ONERA OA206 at position 50\% of span length

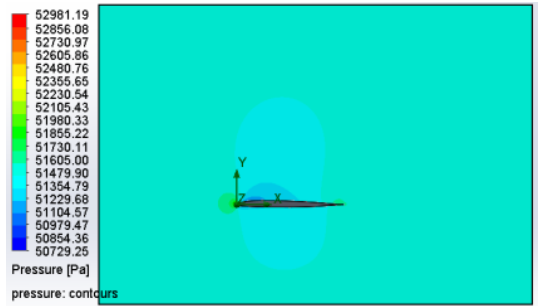

(a) $\mathrm{AoA} 0^{\circ}$

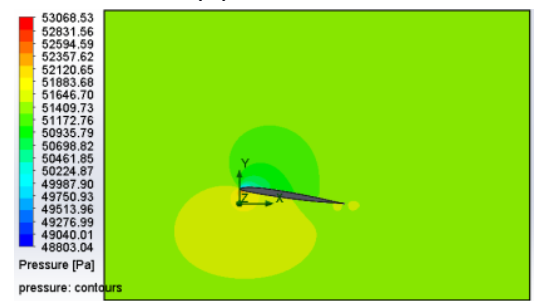

(c) $\operatorname{AoA} 8^{\circ}$

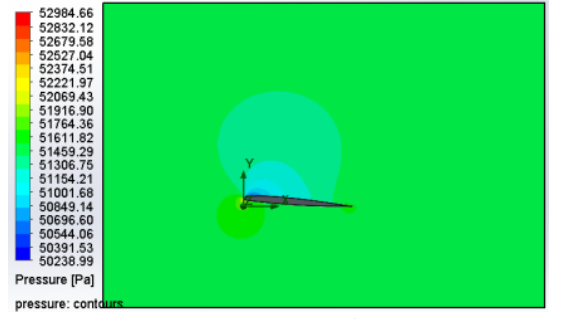

(b) $\mathrm{AoA} 4^{\circ}$

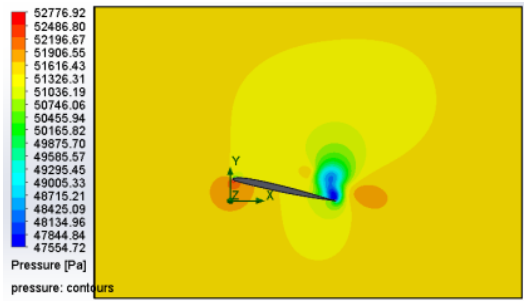

(d) $\operatorname{AoA} 12^{\circ}$ 


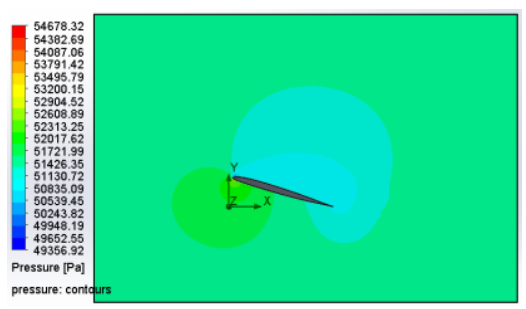

(e) AoA $16^{\circ}$

Figure 9. Pressure contour of airfoil ONERA OA206 at position $75 \%$ of span length

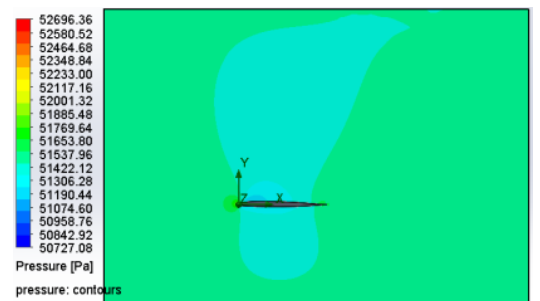

(a) $\operatorname{AoA} 0^{\circ}$

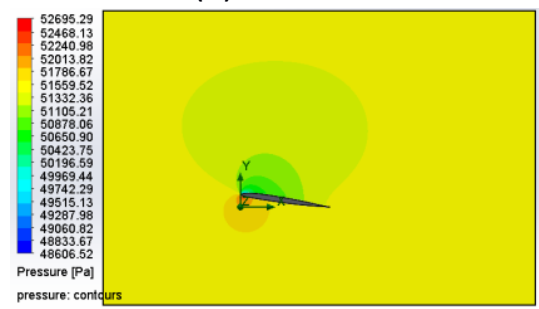

(c) $\operatorname{AoA} 8^{\circ}$

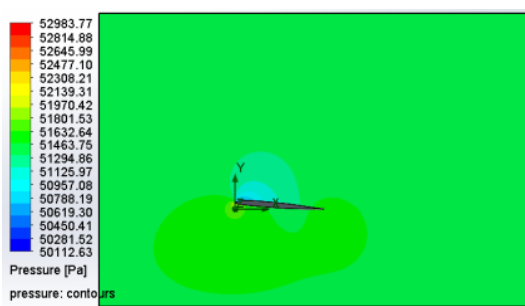

(b) $\operatorname{AoA} 4^{\circ}$

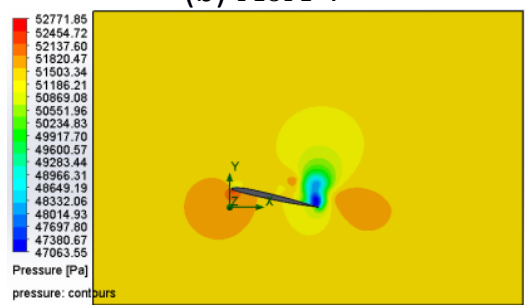

(d) AoA $12^{\circ}$

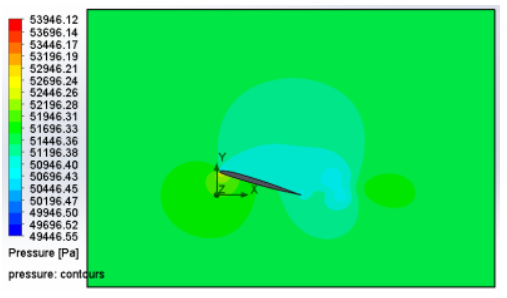

(e) AoA $16^{\circ}$

Figure 10. Pressure contour of airfoil ONERA OA206 at position $100 \%$ of span length

Through the pressure plots in Figure 6 to Figure 10 shows the upper and lower pressure values for each airfoil with a different AoA on each chord. This value is used to determine the value of the pressure coefficient $\left(C_{\mathrm{p}}\right)$ on the surface of the airfoil. Based on those Figures, it can also be seen that the difference between bars is $0.25 \% ; 0.26 \% ; 0.43 \% ; 0.52 \%$; and $0.53 \%$. Therefore, the difference between the bars contained in each AoA shows that the greater the AoA, the greater the distance between the bars. This is because the greater the AoA, the leading edge will also shift upwards ( $y+$ axis direction) so that the measured distance from the initial axis will be further away. 


\section{Effect of AoA on $C_{p}$}

Variation of AoA related to the $C_{\mathrm{P}}$ values on ONERA OA206 wing can be seen as below Figures and Tables:

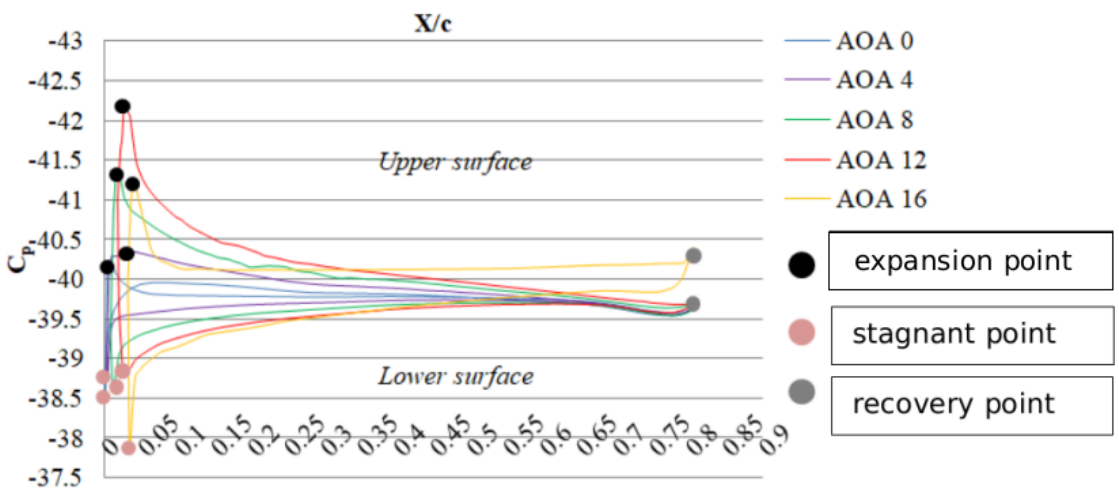

Figure 11. Graph of $C_{p}$ values about chord length $0 \%$ on the airfoil

Table 5. Average Pressure $\mathrm{C}_{\mathrm{p}}$ lower and $\mathrm{C}_{\mathrm{p}}$ upper on airfoil ONERA OA206 at chord length 0\%

\begin{tabular}{ccccc}
\hline $\mathbf{y} / \mathbf{b}$ & chord $(\mathbf{m})$ & AoA $\left(^{\circ}\right)$ & $\overline{\boldsymbol{C}_{\boldsymbol{p}}}$ lower & $\overline{\boldsymbol{C}_{\boldsymbol{p}}}$ upper \\
\hline & & 0 & -39.78 & -39.58 \\
& & 4 & -39.52 & -39.87 \\
$0 \%$ & 0.806 & 8 & -39.40 & -40.13 \\
& & 12 & -39.55 & -40.63 \\
& & 16 & -39.54 & -40.32 \\
\hline
\end{tabular}

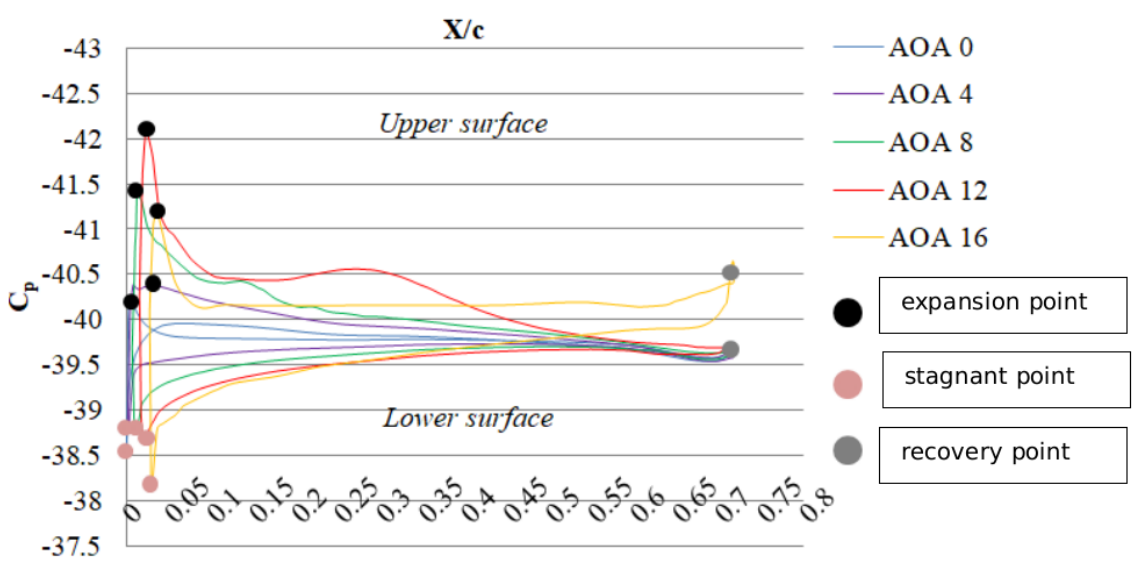

Figure 12. Graph of $C_{p}$ values about chord length $25 \%$ on the airfoil 
Computational and Experimental Research in Materials and Renewable Energy (CERiMRE)

Volume 2, Issue 2, page 81-97

eISSN : 2747-173X
Submitted : August 2, 2019

Accepted : October 15, 2019

Online : November 24, 2019

doi : 10.19184/cerimre.v2i2.27374

Table 6. Average Pressure $C_{p}$ lower and $C_{p}$ upper on airfoil ONERA OA206 at chord length $25 \%$

\begin{tabular}{ccccc}
\hline $\mathbf{y} / \mathbf{b}$ & Chord $(\mathbf{m})$ & AoA $\left({ }^{\circ}\right)$ & $\overline{\boldsymbol{C}_{\boldsymbol{p}}}$ lower & $\overline{\boldsymbol{C}_{\boldsymbol{p}}}$ upper \\
\hline & & 0 & -39.78 & -39.59 \\
& & 4 & -39.50 & -39.91 \\
$25 \%$ & 0.718 & 8 & -39.45 & -40.18 \\
& & 12 & -39.46 & -40.57 \\
& & 16 & -39.67 & -40.36 \\
\hline
\end{tabular}

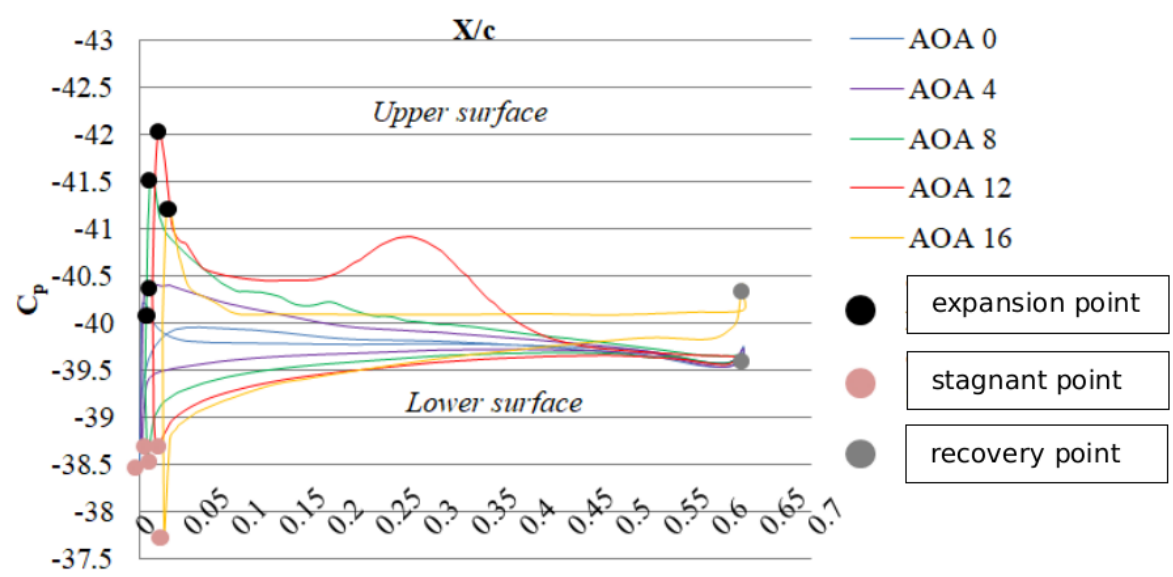

Figure 13. Graph of $C_{p}$ values about chord length $50 \%$ on the airfoil

Table 7. Average Pressure $C_{p}$ lower and $C_{p}$ upper on airfoil ONERA OA206 at chord length $50 \%$

\begin{tabular}{ccccc}
\hline $\mathbf{y} / \mathbf{b}$ & Chord $(\mathbf{m})$ & AoA $\left(^{\circ}\right)$ & $\overline{\boldsymbol{C}_{\boldsymbol{p}}}$ lower & $\overline{\boldsymbol{C}_{\boldsymbol{p}}}$ upper \\
\hline & & 0 & -39.78 & -39.59 \\
& & 4 & -39.51 & -39.93 \\
$50 \%$ & \multirow{2}{*}{0.630} & 8 & -39.42 & -40.20 \\
& & 12 & -39.42 & -40.60 \\
& & 16 & -39.56 & -40.32 \\
\hline
\end{tabular}


Computational and Experimental Research in Materials and Renewable Energy (CERiMRE)

Volume 2, Issue 2, page 81-97

eISSN : 2747-173X
Submitted : August 2, 2019

Accepted : October 15, 2019

Online : November 24, 2019

doi : 10.19184/cerimre.v2i2.27374

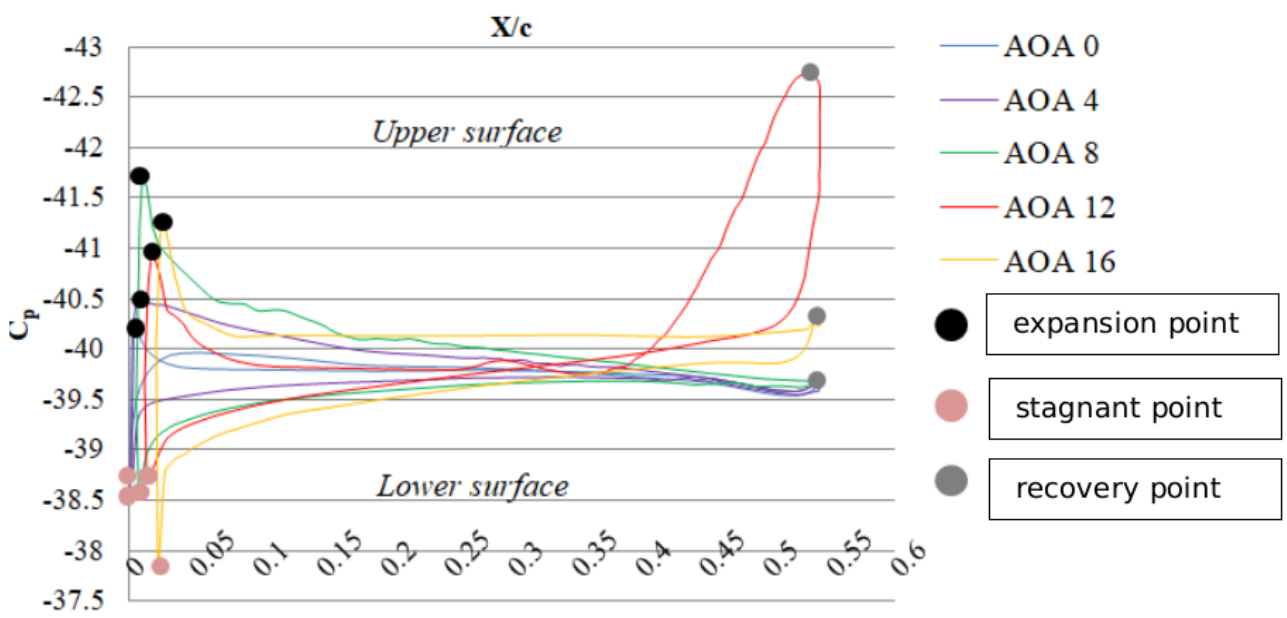

Figure 14. Graph of $C_{p}$ values about chord length $75 \%$ on the airfoil

Table 8. Average Pressure $C_{p}$ lower and $C_{p}$ upper on airfoil ONERA OA206 at chord length $75 \%$

\begin{tabular}{ccccc}
\hline $\mathbf{y} / \mathbf{b}$ & Chord $(\mathbf{m})$ & AoA $\left(^{(}\right)$ & $\overline{\boldsymbol{C}_{\boldsymbol{p}}}$ lower & $\overline{\boldsymbol{C}_{\boldsymbol{p}}}$ upper \\
\hline & & 0 & -39.78 & -39.59 \\
& & 4 & -39.53 & -39.94 \\
$75 \%$ & \multirow{3}{*}{0.541} & 8 & -39.42 & -40.29 \\
& & 12 & -40.12 & -40.72 \\
& & 16 & -39.53 & -40.34 \\
\hline
\end{tabular}
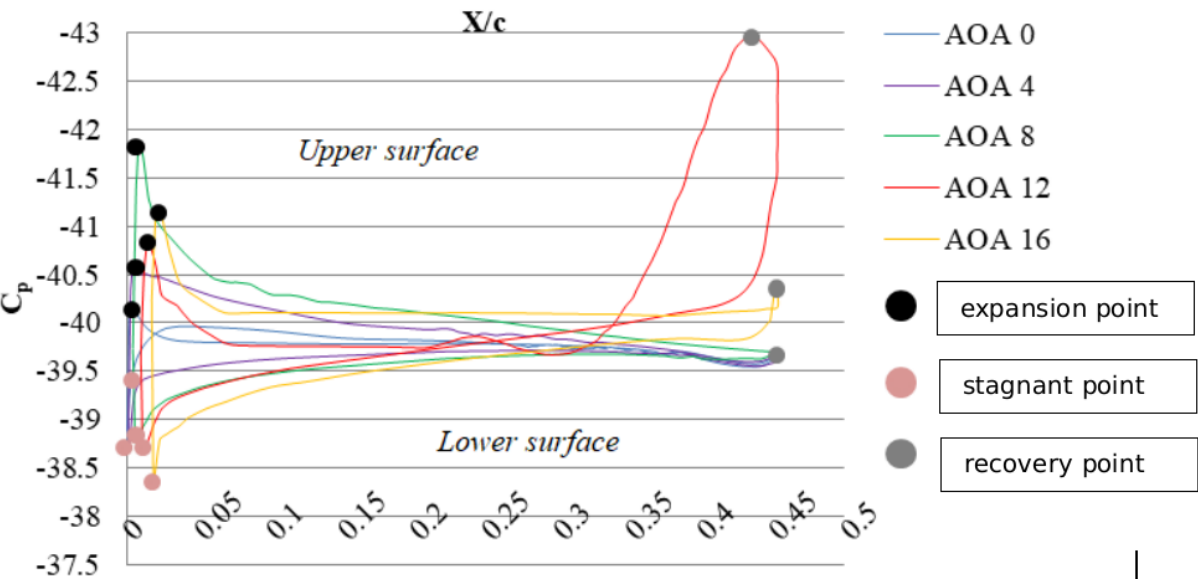

Figure 15. Graph of $C_{p}$ values about chord length $100 \%$ on the airfoil 
Table 9. Average Pressure $C_{p}$ lower and $C_{p}$ upper on airfoil ONERA OA206 at chord length $100 \%$

\begin{tabular}{ccccc}
\hline $\mathbf{y} / \mathbf{b}$ & Chord $(\mathbf{m})$ & AoA $\left(^{\circ}\right)$ & $\overline{\boldsymbol{C}_{\boldsymbol{p}}}$ lower & $\overline{\boldsymbol{C}_{\boldsymbol{p}}}$ upper \\
\hline & & 0 & -39.75 & -39.66 \\
& & 4 & -39.51 & -39.97 \\
$100 \%$ & 0.4533 & 8 & -39.49 & -40.40 \\
& & 12 & -40.11 & -40.71 \\
& & 16 & -39.60 & -40.32 \\
\hline
\end{tabular}

Based on Figures 11 to 15 and Tables 5 to 9 , it can be seen that the $C_{p}$ at the bottom is greater than the $C_{p}$ at the top of the airfoil. This is because when the airfoil is given AoA, the air molecules moving past the top surface will be forced to move at a higher speed than the air molecules on the bottom surface. There is a higher velocity on the top surface because the molecules have to travel a longer distance due to the curvature on the top surface. This increase in velocity causes a decrease in pressure at the top of the airfoil. Whereas, Based on the upper and lower values contained in Table 5 to Table 9, it can be used to determine the value of $C_{\mathrm{L}}$.

\section{Effect of AoA on $C_{L}$}

The $C L$ value is obtained from the upper and lower contained in the results and previous discussion, using Equation 2.2. Based on research on the effect of AoA on the $\mathrm{CL}$ value on the wing of the ONERA OA206 aircraft, the results of the graph are shown in Figure 16.

It can be seen that the greater the AoA given, the greater the $C_{\llcorner}$produced. However, the increase in $C_{\llcorner}$has a maximum limit $\left(C_{\llcorner}\right.$max) which is at the maximum AoA. When the AoA is increased beyond the maximum AoA, it will cause a stalling effect. The stall effect is an effect that causes the $C_{L}$ value to not increase beyond the maximum $C_{L}\left(C_{L} \max \right)$ or can also decrease the next $C_{L}$ value. The $C_{L}$ airfoil chart is also shown with the $0 \%$ chord position, $25 \%$, and $50 \%$ of the wingspan $(\mathrm{y} / \mathrm{b})$. The graph shows that the $C_{\llcorner}$of the airfoil (ONERA OA206) increases with the increase in $A o A$. The increase in $C_{\llcorner}$reached the maximum limit $(C L$ max) at AoA $12^{\circ}$ with a $C_{L}$ value of $1.076369 ; 1.111437$; and 1.171477 . Meanwhile, at $A_{0 A} 16^{\circ} C_{L}$, there was a decrease (stall) with a value of $0.785616 ; 0.69067$; and 0.761881 .

Next is the $C_{L}$ airfoil chart at the $75 \%$ and $100 \%$ chord positions of the wingspan $(y / b)$. Different from before, in this position the airfoil $C_{L}$ value increases and reaches a maximum at an earlier AoA of $8^{\circ}$. At $A \circ A 8^{\circ}$ the measured $C_{L}$ values were 0.870415 and 0.910242 . While at $A \circ A 12^{\circ}$ and $16^{\circ} \mathrm{C}_{\mathrm{L}}$ decreased (stall) with values of $(0.595776 ; 0.595336)$ and $(0.806139 ; 0.716721$.

Based on the $C_{L}$ max and stall conditions that occur in each chord, the maximum AoA that can be applied to one wing of the ONERA OA 206 aircraft is $8^{\circ}$. If sorted from the chord position of $0 \%$ (wing base) to $100 \%$ (wingtip), then the measured $C_{L}$ value is $0.72661 ; 0.730036 ; 0.784276$; 0.870415 ; and 0.910242 . It can be seen that the higher the position of the airfoil, the higher the measured $C_{L}$. This is because the higher the position of the airfoil, the smaller the chord size, so that the surface area of the airfoil is also smaller and causes the resulting lift to be greater. The lifting force is represented by the value of $C_{L}$. 


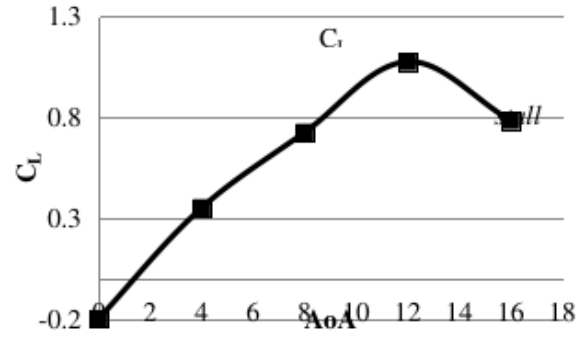

(a)

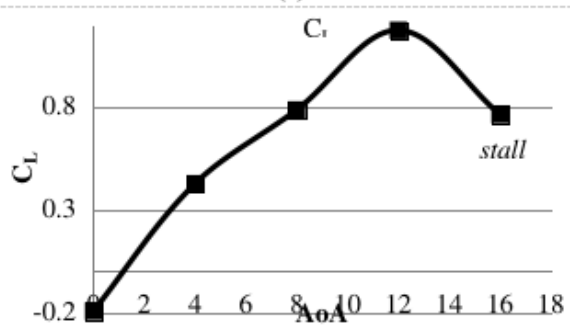

(c)

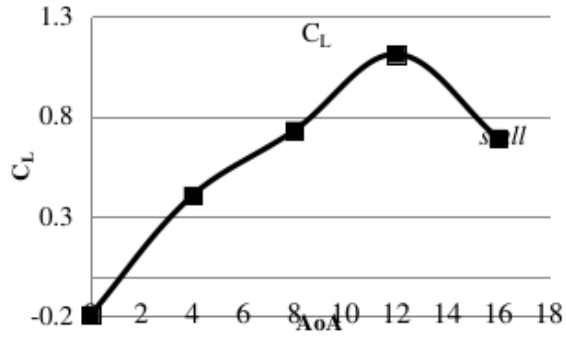

(b)

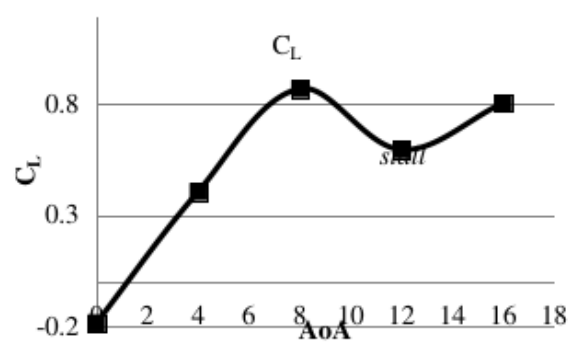

(d)

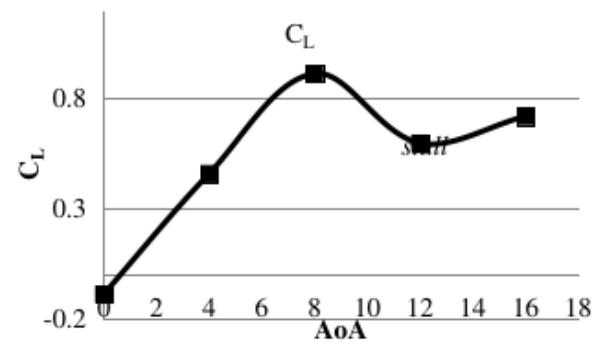

(e)

(a) Chord 0\%; (b) Chord 25\%; (c) Chord 50\%; (d) Chord 75\%; (e) Chord 100\%

Figure 16. $\mathrm{C}_{\mathrm{L}}$ graph on AoA at chord length $0 \%$ airfoil ONERA OA206

\section{Conclusion}

1. Different upper and lower pressure valuesfor each airfoil with different AoA on each chord. The percentage increase in the difference in bars at AoA $0^{\circ}$ to AoA $16^{\circ}$ respectively is $0.25 \%$; $0.26 \% ; 0.43 \%$; $0.52 \%$; and $0.53 \%$. Therefore, the difference between the bars contained in each AoA shows that the greater the AoA, the greater the distance between the bars.

2. The greater the AoA given, the more the location of the expansion point and stagnation point shifts to the right. Other than that. Cp at the bottom (lower) is greater than the top of the airfoil. This is because the air molecules that pass through the top surface are forced to move at high speed so that the pressure on the top of the airfoil is reduced.

3. $C_{\mathrm{L}}$ at $0 \%$ to $50 \%$ position increases when given $\mathrm{AoA} 0^{\circ}$ to $12^{\circ}(C \mathrm{~L}$ Max) and decreases at AoA $16^{\circ}$ (stall). Meanwhile, $C_{\mathrm{L}}$ at $75 \%$ to $100 \%$ position increased when given $A \circ A \quad 0^{\circ}$ to $8^{\circ}$ $\left(C_{\mathrm{L}} \max \right)$ and decreased at AoA $12^{\circ}$ (Stall). So that, The maximum AoA that can be applied to one wing of the ONERA OA 206 aircraft is $8^{\circ}$. The higher the position of the airfoil, the higher the measured $C_{\mathrm{L}}$.

4. The greater the pressure, the $C p$ at the expansion point will be smaller and cause $C \mathrm{~L}$ to increase. At the maximum AoA the measured pressure is the largest and $C p$ at the 
expansion point is the smallest so that $C_{\mathrm{L}}$ has the greatest value $\left(C_{\mathrm{L}} \max \right)$. When it exceeds the maximum AoA, the pressure begins to decrease and the expansion point $C p$ begins to increase so that the $C_{\mathrm{L}}$ stalls.

\section{References}

[1] Airfoiltools, 2018, Airfoil Tools, http://airfoiltools,com/search/index, accessed on January 13, 2018.

[2] Z. T. Applin, 1995, Pressure Distributions From Subsonic Tests of a NACA 0012 Semispan Wing Model, NASA Technical Memorandum 110148, page 17-22.

[3] J. Bridenstine, 2018, Wing Geometry Definitions, NASA, https://www.grc.nasa.gov/www/k12/airplane/geom.html, accessed on Februari 20, 2018.

[4] F. Fossati, 2009, Aero-hydrodynamics and the Performance of Sailing Yachts: The Science Behind Sailing Yachts and Their Design, London: A\&amp;C Black:

[5] Y. Harahap and H. Sasongko, 2003, Analisa Karakteristik Distribusi Tekanan dan Kecepatan Pada Bodi Aerodinamika Airfoil Dengan Metoda Panel Dalam Fenomena "Flow Around Body", Jurnal Teknik Mesin volume 5 (1), page 22 - 35.

[6] G. Jatisukamto and M. Sari, 2018, Analisis Airfoil Double-Slot Flap LS(01)-0417 MOD dengan Airfoil Tanpa Flap Nasa SC(2) 0610, Jurnal Energi dan Manufaktur, volume 11 (2), page 49 - 53.

[7] D. Kurniawan, 2018, Analisis Aerodinamika pada Sayap V-Tail UAV MALE (Unamanned Aerial Vehicle Medium Altitude Long Endurance) Akibat Laju Aliran Udara dengan Menggunakan Software Computational Fluid Dynamic (CFD), Skripsi, Yogyakarta: Jurusan Teknik Mesin Fakultas Teknologi Industri Universitas Islam Indonesia.

[8] D. Lakshman, P. Saravanan, and P. Vadivelu, 2018, Performance Characteristics of ONERA-M6 Wing for High Altitude Long Endurance Unmanned Aerial Vehicles, International Journal of Pure and Applied Mathematics volume 119 (18), page 10-13.

[9] M. Mulyadi, 2014, Analisis Aerodinamika pada Sayap Pesawat Terbang dengan Menggunakan Software Berbasis Computational Fluid Dynamics (CFD), Skripsi, Jakarta: Jurusan Teknik Mesin Universitas Gunadarma.

[10] S. Murakami, 1993, Computational Wind Enginering 1 Tokyo, Elsevier Science, https://www.sciencedirect.com/topics/engineering/pressure-coefficient, accessed on Februari 3, 2018.

[11] NASA, 2015, ONERA M6 Wing, https://www.grc.nasa.gov/WWW/wind/valid/m6wing/ m6wing.html, accessed on Januari 2, 2018.

[12] ONERA, 2018, ONERA reveals its 70 years of history, https:/www.onera.fr/en/history/ onera-70-years-the-facts-prior-to-its-creation, accessed on Januari 2, 2018.

[13] S. F. Saputra and S. Agustian, 2018, Analisa Pengaruh Putaran Blade dan Arah Sudut Serang terhadap Koefisien Drag dan Lift pada Model Prototipe Airfoil NACA 0012 dengan Menggunakan Alat Uji Wind Tunnel Open Circuit untuk Sarana Laboratorium Fluida, Skripsi, Surabaya: Program Studi Teknik Mesin Universitas 17 Agustus 1945 Surabaya 
[14] V. Schmitt and F. Charpin, 1979, Pressure Distributions On the ONERA-M6-Wing at Transonic Mach Numbers (Experimental Data Base for Computer), In AGARD-AR-138, London: Office National D'Etudes Et De Recherches Aerospatiales.

[15] H. Sogukpinar and I. Bozkurt, 2015, Calculation of Aerodynamic Performance Characteristics of Airplane Wing and Comparing with the Experimental Measurement, International Journal of Engineering Technologies 1 (2), page 84-86.

[16] A. Suryadi, 2016, Analisa Pengaruh Sudut Serang Hidrofoil terhadap Gaya Angkat Kapal Trimaran Hidrofoil, Tugas Akhir, Surabaya: Jurusan Teknik Sistem Perkapalan Fakultas Teknologi Kelautan Institut Teknologi Sepuluh Nopember Surabaya.

[17] J. Tu, G. H. Yeoh and C. Liu, 2018, Computational Fluid Dynamics, Cambridge: Elsevier Ltd.

[18] Vijay, 2015, Airfoil Terminology, http://wwwaeroforum.blogspot.com/2015/03/airfoilterminology-air-foil-isprimary.html, accessed on Januari 28, 2018.

[19] S. Xiuliung, L. Liang and L. Guojun, 2013, Transonic Flow of Moist Air around the ONERA M6 Wing with Non-equilibrium and Homogeneous Condensation, Research Journal of Applied Sciences, Engineering and Technology 6 (10), page 1825-1833.

[20] M. J. Zeldes, 2017, Airfoil in General, http://www.dynamicflight.com/aerodynamics/airfoils/, accessed on Januari 28, 2018. 